\title{
Three new Ceratocystis spp. in the Ceratocystis moniliformis complex from wounds on Acacia mangium and $A$. crassicarpa
}

\author{
Marthin Tarigan ${ }^{1}$, Marelize Van Wyk ${ }^{2}$, Jolanda Roux ${ }^{1}$, Budi Tjahjono ${ }^{3}$ and Michael J. \\ Wingfield ${ }^{1}$
}

(1) Department of Microbiology and Plant Pathology, Forestry and Agricultural Biotechnology Institute (FABI), University of Pretoria, Pretoria, 0002, South Africa

(2) Department of Genetics, Forestry and Agricultural Biotechnology Institute (FABI), University of Pretoria, Pretoria, 0002, South Africa

(3) PT Riau Andalan Pulp and Paper (RAPP), P.O. Box 1080, Pekanbaru-Riau, Sumatra, Indonesia

Marelize van Wyk

Email: marelize.vanwyk@fabi.up.ac.za

\begin{abstract}
The genus Ceratocystis includes many important tree pathogens and agents of sap stain. These fungi have a global distribution and commonly infect wounds on trees. During a survey of woundinfecting pathogens in the genus Ceratocystis on plantation-grown Acacia mangium trees in Indonesia, several isolates resembling Ceratocystis moniliformis sensu lato (s.l.) were obtained. The aim of this study was to identify these isolates and to test their pathogenicity on commercially grown Acacia spp. in the country. Use was made of morphology and comparisons of DNA sequence data for the ITS, $\beta$-tubulin, and transcription elongation factor 1- $\alpha$ gene regions to identify the isolates. Three previously undescribed species in the C. moniliformis s.l. species complex were identified and are described here as $C$. inquinans sp. nov., $C$. sumatrana sp. nov., and $C$. microbasis sp. nov. Pathogenicity trials on Acacia mangium and $A$. crassicarpa in the greenhouse and in the field indicated that all three species have the potential to infect $A$. mangium and A. crassicarpa, although they are not considered important pathogens.
\end{abstract}

\section{Introduction}

Fungal pathogens represent a serious limiting factor to the success and long-term sustainability of commercial plantations in Kalimantan and Sumatra (Indonesia). These plantations, made up especially of nonnative Acacia mangium Willd. and A. crassicarpa A. Cunn. ex Benth., are vulnerable because of their homogeneous nature. The trees have also been separated from their natural enemies, and these are likely to appear and proliferate in time (Old et al. 2000, 2003). Similarly, some native pathogens will likely adapt to infect these trees, as has happened elsewhere with Acacia spp. (Roux et al. 2007). The uniform distribution of these plantation-grown trees will also enhance their vulnerability, as has already been found in the case of diseases that affect Eucalyptus plantations (Old et al. 2003).

Acacia mangium trees grown in plantations in Indonesia are commonly wounded during their cultivation. They tend to have multiple leader stems (Srivastava 1993; Lee and Arentz 1997), and it is standard practice in pulpwood plantations to prune or "single" the stems at 4-8 months of age (Beadle et al. 2007). In this regard, pruning wounds on young $A$. mangium trees in Indonesian plantations have been recognized as becoming infected with pathogens causing lesions that expand 
substantially beyond the physical damage associated with pruning. Various fungi are known to infect pruning wounds on trees, and Ceratocystis spp. represent well-recognized examples of wound-infecting pathogens (Zalasky 1965; Teviotdale and Harper 1991; Kile 1993).

The genus Ceratocystis is well known to accommodate species that infect wounds on trees (Kile 1993). These species include a number of economically important pathogens, mostly residing in the Ceratocystis fimbriata s.l. species complex. Examples of tree-infecting pathogens include $C$. albifundus M.J. Wingf., De Beer \& Morris, a pathogen of Australian Acacia spp. resulting in wilt and death of $A$. mearnsii De Wild. and A. decurrens Willd. trees in Africa (Morris et al. 1993; Wingfield et al. 1996; Roux and Wingfield 1997; Roux et al. 2005), and C. fimbriata s.l., the causal agent of canker and wilt of $A$. decurrens in Brazil (Ribeiro et al. 1988). Other Ceratocystis spp., such as those in the $C$. monilformis s.l. species complex, are not known to cause disease and death of trees but may result in staining of the timber (Hedgcock 1906).

The taxonomy of $C$. moniliformis s.l. and fungi similar to it has presented considerable challenges in the past and especially before the advent of DNA sequence comparisons. Traditionally, all Ceratocystis spp. with hat-shaped ascospores, with conical spines on their ascomatal bases, and in which the bases of the ascomatal necks represented a disk-like structure that easily becomes detached from the ascomatal bases were classified as C. moniliformis (Hedgc.) C. Moreau (Hedgcock 1906; Hunt 1956; Van Wyk et al. 2004, 2006a). It is, however, now recognized that many of the fungi identified as C. moniliformis in the past represent distinct species (Van Wyk et al. 2004, 2006a). Thus, the $C$. moniliformis s.l. species complex includes at least seven distinct species, occurring on a broad range of hosts worldwide. Accurate identification of species in this complex relies on a combination of multigene sequence comparisons and morphology (Van Wyk et al. 2006a).

The aim of this study was to identify a collection of Ceratocystis isolates, which based on morphology resembled species in the $C$. moniliformis s.l. species complex. These isolates were collected from the stems of $A$. mangium trees that had been artificially wounded in a study to obtain information on the Ceratocystis spp. present on Acacia spp. in Indonesia. Identifications were based on morphology and comparisons of DNA sequence data. Furthermore, their ability to infect $A$. mangium and $A$. crassicarpa was evaluated using pathogenicity trials in the greenhouse and in the field.

\section{Materials and Methods}

\section{Fungal isolates}

Wounding trials were established on 1-year-old A. mangium and A. crassicarpa trees in the Teso area, Riau Province, during the dry and wet periods from December 2006 to March 2007, following the method described by Barnes et al. (2003). Fifteen trees of each species were randomly selected and wounded. Five weeks after wound establishment, samples of discolored wood and bark were collected from the wounds, wrapped in newspaper to maintain a moist environment, and taken to the laboratory for examination.

Fungi were isolated from the wood and bark specimens by lifting spore masses from the apices of ascomata and transferring these to $2 \%(\mathrm{w} / \mathrm{v})$ malt extract agar (MEA; $15 \mathrm{~g}$ agar, $20 \mathrm{~g}$ malt extract) (Biolab, Midrand, South Africa). When no fruiting bodies were observed, wood tissue was incubated in sealed plastic bags containing moistened tissue paper for 4-10 days, until sporulation was observed, after which single spore masses were lifted from the tips of the ascomata. All isolates collected in this study are maintained in the culture collection (CMW) of the Forestry and Agricultural Biotechnology Institute (FABI), University of Pretoria, South Africa. Representative 
isolates have been deposited in the culture collection of the Centraalbureau voor Schimmelcultures (CBS), Delft, Netherlands and dried specimens were deposited at the National Herbarium of South Africa (PREM), Pretoria.

\section{DNA extractions}

Nine Ceratocystis isolates were selected randomly, based on differences in culture morphology and grown on $2 \%$ MEA at $22^{\circ} \mathrm{C}$ for 1 week. Using sterilized scalpels, the mycelium was scraped from the surface of the agar and transferred to $1.5-\mathrm{ml}$ Eppendorf tubes and lyophilized overnight. The lyophilized fungal mycelium was placed into liquid nitrogen and crushed to a fine powder using a glass rod or mechanical grinder (Ball Mills machine; Retsch, Haan, Germany). The DNA was extracted using the method described by Van Wyk et al. (2006a).

\section{PCR amplification, sequencing, and analyses}

Polymerase chain reaction (PCR) amplification was carried out for three gene regions: these included the internal transcribed spacer regions (ITS), including the 5.8S gene of the ribosomal RNA (rRNA) operon, and portions of the $\beta$-tubulin ( $\beta \mathrm{t}$ ) and transcription elongation factor $1-\alpha$ (EF1- $\alpha$ ) regions. Each gene region was amplified using the primers ITS1 and ITS4 (White et al. 1990), $\beta \mathrm{t} 1 \mathrm{a}$ and $\beta \mathrm{t} 1 \mathrm{~b}$ (Glass and Donaldson 1995), and EF1-728F and EF1-986R (Carbone and Kohn 1999), respectively. The PCR reaction mixtures were $25 \mu \mathrm{l}$ in total, consisting of $0.5 \mu 110$ $\mathrm{mM}$ forward and reverse primers, $2 \mu 110 \mathrm{mM}$ dNTP mixture [2.5 mM of each deoxynucleotide triphosphate (dNTP)], $0.5 \mu \mathrm{l}(2 \mathrm{U})$ DNA Taq enzyme (Roche Molecular Biochemicals, Almeida, CA, USA), $2.5 \mu 110 \times$ concentration buffer containing $\mathrm{MgCl}_{2}(3.5 \mathrm{mM}), 2 \mu \mathrm{l} \mathrm{DNA}(2-10 \mathrm{ng})$, and $17 \mu l$ deionized water. The PCR program, electrophoresis conditions, and DNA purification procedures were as described by Van Wyk et al. (2006a).

Sequencing of purified PCR amplicons was carried out in both directions using the ABI PRISM Big Dye Terminator Cycle Sequencing Ready Reaction Kit, following the manufacturer's protocols (Applied Biosystems, Foster City, CA, USA). Sequencing of each gene region was achieved using the same primers as those used for the PCR reactions. After cleaning, the final sequence products were run on an ABI PRISM 3100 auto sequencer (Applied Biosystems). Sequence electropherograms were analyzed using Sequence Navigator version 1.0.1 (Applied Biosystems).

BLAST analyses were used to compare the sequences obtained with those of Ceratocystis spp. that are available in GenBank (The National Centre for Biological Information; http://www.ncbi.nlm.nih.gov/). Thereafter, sequences published for Ceratocystis spp. were incorporated into the data sets for each gene region, together with those for the isolates from wounds on the Acacia spp., and aligned using the online interface MAFFT version 6 (http://align.bmr.kyushu-u.ac.jp/mafft/software/source.html). Alignments were confirmed manually and deposited into TreeBASE (Treebase S2353).

After alignment, sequence data for the Indonesian Ceratocystis spp. were analyzed using various programs. A partition homogeneity test was run using PAUP (phylogenetic analysis using parsimony) version $4.0 \mathrm{~b} 10^{*}$ to determine whether the data from the three gene regions could be combined (Swofford 2002). Data for each data set were analyzed using PAUP version 4.0b10* (Swofford 2002). Gaps were treated as "newstate", and trees were obtained via stepwise addition of 1000 replicates. The Mulpar option was in effect. Bootstrap confidence intervals using 1000 replicates were calculated. Ceratocystis virescens (R.W. Davidson) C. Moreau was used as the outgroup taxon.

The model of nucleotide substitution for each gene region was determined using MrModeltest 2.2 
(Nylander 2004), and the models obtained were used in Bayesian analysis with MrBayes version 3.1.1. (Ronquist and Huelsenbeck 2003). Bayesian probabilities of Markov Chain Monte Carlo (MCMC) algorithms combining each model test obtained were used to calculate support for the phylogenetic trees. Following the MCMC procedure, 1 million random trees were generated with four chains and sampled every 100th generation. Samples were taken only from trees after convergence after the trees outside the point of convergence had been discarded.

\section{Culture characteristics and morphology}

Two, or where available three, isolates representing each of the groups identified using DNA sequence comparisons were grown on $2 \%$ MEA for 1 week at $22^{\circ} \mathrm{C}$. These isolates were then used for growth comparisons. Mycelial discs taken from the edge of an actively growing culture were cut using a 5-mm cork borer and placed at the centers of 90-mm Petri dishes containing $2 \%$ MEA. Discs representing each isolate were placed on five plates for each treatment, and these were incubated at $4{ }^{\circ} \mathrm{C}$, and between 10 and $35^{\circ} \mathrm{C}$ at $5^{\circ} \mathrm{C}$ intervals. Two diameter growth measurements for each colony, at right angles to each other, were taken 2 days after incubation, and averages were computed. The experiment was repeated once.

The morphology of the Ceratocystis isolates was described from 1-week-old cultures grown on 2\% MEA. The color of cultures was described using the color charts of Rayner (1970). Fruiting structures were mounted in lactic acid (85\%) for observation and measurement. Fifty measurements of characteristic structures for each isolate representing the main groups, and 10 measurements for one additional isolate in each group, were made using a Carl Zeiss microscope and a Zeiss Axiovision camera system (Zeiss, Oberkochen, Germany). The average (mean), standard deviation (SD), maximum ( $\max$ ), and minimum $(\min )$ measurements were calculated and are presented as (min-) mean minus SD - mean plus SD (-max).

\section{Pathogenicity tests}

\section{Greenhouse inoculations}

Pathogenicity tests were conducted on the stems of 1-year-old A. mangium and A. crassicarpa seedlings (15-mm-diameter size) grown in 20-cm-diameter plastic bags containing a mixture of topsoil and compost. The seedlings were placed in a greenhouse where the temperature and humidity was adjusted for optimum growth of the seedlings $\left(30^{\circ} \mathrm{C}\right)$. One to three isolates representing the various groups of Ceratocystis (group 1 = CMW 21106; group 2 = CMW 21109, CMW 21111, and CMW 21113; group 3 = CMW 21115, CMW 21117, and CMW 21118) identified using DNA sequence data were used for the inoculations. Wounds were made on the stems of the seedlings ( $\sim 30 \mathrm{~cm}$ above soil level) using a sterilized cork borer, and inoculations were carried out by inserting an agar disc taken from the edge of an actively growing colony grown on $2 \%$ MEA into the wound, with the mycelium facing the exposed cambium. Parafilm (Pechiney, Menasha, WI, USA) was used to seal the wounds after inoculation to avoid contamination and desiccation. Five seedlings of each Acacia sp. were inoculated with each of the test fungi, and five seedlings were similarly inoculated with sterile MEA plugs to serve as controls.

Ten days after inoculation, the Parafilm was removed from the inoculation sites and the lengths of the lesions in the xylem were measured. A piece of symptomatic stem tissue was taken from the inoculation site for five seedlings representing each test isolate and placed into moist chambers to induce the production of fruiting structures. Spores from these structures were then transferred to $2 \%$ MEA to verify the identity of the inoculated isolate and to fulfill the requirements of Koch's postulates. Analysis of variance (ANOVA) was calculated for all data obtained using SAS statistical analyses (SAS Version 8.2, 2001). 


\section{Field inoculations}

Pathogenicity trials were conducted on 1-year-old A. mangium and A. crassicarpa trees in commercial plantations in Indonesia. Trees ranged from 70 to $90 \mathrm{~mm}$ in diameter at breast height. The same isolates as those used in the greenhouse inoculations were used to inoculate 20 trees of each of the Acacia species for each Ceratocystis isolate. An additional 20 trees of each Acacia species were inoculated with sterile MEA plugs to serve as controls. For inoculation, a wound was made on the tree stems using a sterilized cork borer (10-mm diameter) and inoculations were carried out by inserting an agar disc of the same size, taken from the edges of actively growing colonies on $2 \%$ MEA. These discs were placed into the inoculation points, with the mycelium facing the exposed cambium. The wounds were sealed with wrapping tape after inoculation to avoid contamination and desiccation of the inoculum and wounds.

Six weeks after inoculation, tree diameters at the inoculation points and the lengths of lesions produced on the stems were measured. Reisolations were made by taking a piece of symptomatic tissue from the area associated with the inoculation points for five trees of each isolate and placing these in moist chambers to induce sporulation. Spore masses were then taken from the tips of fruiting structures and plated on 2\% MEA to verify the presence of the inoculated fungus. Analysis of variance (ANOVA) was calculated for all data obtained using SAS statistical analyses (SAS Version 8.2, 2001). The entire field experiment was repeated once.

\section{Results}

\section{Fungal isolates}

Fourteen Ceratocystis isolates, resembling C. moniliformis s.l., were obtained from 3 of the $15 \mathrm{~A}$. mangium trees wounded in this study. No isolates were obtained from wounded A. crassicarpa. Of the 14 isolates obtained, 4 were collected from one tree (CMW 21105-21108), 6 isolates (CMW 21109-21114) were collected from a second tree, and 4 isolates (CMW 21115-21118) were obtained from a third tree. Within 2 weeks, all isolates produced mature perithecia containing hatshaped ascospores and a Thielaviopsis anamorph. At the time of sample collection, staining of the vascular tissue was observed on the trees in the vicinity of the wounds.

\section{PCR amplification, sequencing, and analyses}

PCR amplification resulted in fragments of $\sim 500$ base pairs (bp) in size for the ITS and $\beta$ t gene regions; for the EF1- $\alpha$ gene region, amplification resulted in fragments $\sim 300$ bp in size. The partition homogeneity test on the three data sets resulted in a P value of 0.02 , which is an acceptable level to combine the data (Cunningham 1997; Barker and Lutzoni 2002). Thus, all data sets were combined for further analyses.

The combined data set consisted of 1368 characters including gaps, of which 791 characters were constant, 8 were parsimony uninformative, and 569 were parsimony informative. Twelve most parsimonious trees were obtained after analyses, 1 of which was selected for presentation (Fig. 1). This tree had a length of 840 ; consistency index $(\mathrm{CI})=0.867$, homoplasy index $(\mathrm{HI})=0.133$, retention index $(\mathrm{RI})=0.931$, and rescaled consistency index $(\mathrm{RC})=0.825$. 


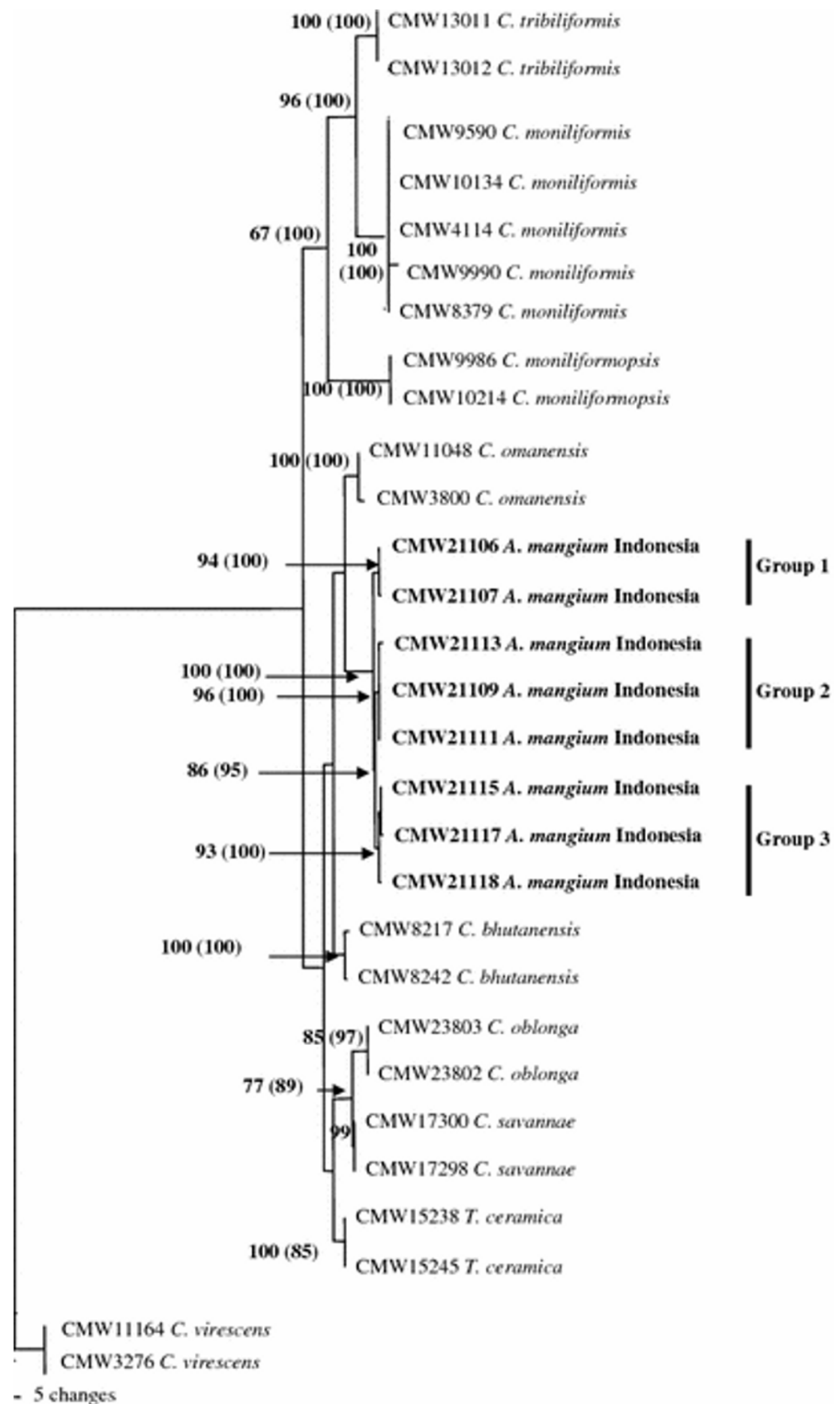


Fig. 1. Phylogenetic tree based on the combined sequence data of three gene regions (ITS, $\beta \mathrm{t}$, and EF1- $\alpha$ ) showing relationships between Ceratocystis moniliformis s.l. isolates used in this study. Isolates shown in bold were isolated from Acacia mangium in Indonesia and sequenced as part of this study. The phylogram was obtained using the heuristic search option based on parsimony. Bootstrap values are indicated, and Bayesian values follow in brackets. Two isolates of $C$. virescens were selected as the outgroup.

Model test analysis produced a GTR + G model [Prset statefreqpr $=\operatorname{dirichlet}(1,1,1,1)$; Lset nst $=$ 6 rates $=$ gamma] for both the ITS and $\beta$ t data sets; for EF1- $\alpha$, it produced a HKY + I model [Prset statefreqpr $=$ dirichlet $(1,1,1,1)$; Lset nst $=2$ rates $=$ propinv $]$. Burn-in was taken at 1000 trees. Bootstrap values followed by Bayesian values in brackets (see Fig. 1) were attached to the branch nodes of the combined datasets. Bayesian values provided strong support to the bootstrap values obtained.

Three distinct groups residing in the C. moniliformis s.l. complex were recognized: these were designated group 1 (CMW 21106, 21107), group 2 (CMW 21109, 21111, 21113), and group 3 (CMW 21115, 21117, 21118). All three groups formed well-resolved clades with posterior probability values for the branch nodes of 94\% (100\%), 96\% (100\%), and 93\% (100\%) for group 1 , group 2, and group 3, respectively (Fig. 1). All these isolates were phylogenetically most closely related to C. omanensis Al-Subhi, M.J. Wingf., M. van Wyk \& Deadman. These results indicated that the three groups representing C. moniliformis s.l. from A. mangium in Riau, Sumatra, represent distinct and undescribed species.

\section{Culture characteristics and morphology}

All three Ceratocystis groups emerging from the phylogenetic analyses showed similar growth rates and temperature optima. All isolates showed optimum growth at $30^{\circ} \mathrm{C}$, with group 1 isolates reaching an average diameter of $67 \mathrm{~mm}$, group 2 isolates reaching an average diameter of $56 \mathrm{~mm}$, and group 3 reaching an average diameter of $63 \mathrm{~mm}$ in 2 days at $30^{\circ} \mathrm{C}$. For all isolates, growth was reduced at 35,20 , and $15^{\circ} \mathrm{C}$. Very slow growth was observed at $10^{\circ} \mathrm{C}$, and no growth was found at $4^{\circ} \mathrm{C}$.

Cultures representing group 1 had hair brown (17"'"i) aerial mycelium whereas those in group 2 and group 3 had cream-buff (19"d) to hair brown (17"''i) aerial mycelium. Within 1-2 weeks, both teleomorph and anamorph structures were produced in all cultures. The ascomatal bases were brown, or dark brown to black, in color and globose to subglobose, with ornamentations in the form of conical spines. The ascomatal bases of group 3 isolates were much smaller and lighter in color than those of group 1 and group 2 isolates. All isolates, irrespective of the group to which they belonged, had necks with disc-like bases. They also all had divergent ostiolar hyphae at the tips of the ascomatal necks, from which hat-shaped ascospores were produced. The ostiolar hyphae of group 3 isolates were shorter than those of group 1 and group 2 isolates. Both primary and secondary phialides were present in the isolates, except for group 3, which only has primary phialides. Primary phialides produced cylindrical conidia, either in chains or singly, whereas secondary phialides produced barrel-shaped conidia, also in chains or singly. None of the isolates representing any of the three groups produced chlamydospores (Table 1). 
Table 1. Morphological characteristics of Indonesian Ceratocystis species collected in this study compared to C. omanensis (Al-Subhi et al. 2006).

\begin{tabular}{|c|c|c|c|c|}
\hline & $\begin{array}{l}\text { C. inquinass } \\
\text { CMW } 21106\end{array}$ & $\begin{array}{l}\text { C. sumatraia } \\
\text { CMW } 21113\end{array}$ & $\begin{array}{l}\text { C. microbasis } \\
\text { CMW } 21117\end{array}$ & $\begin{array}{l}\text { C omanensis } \\
\text { CMW } 11048\end{array}$ \\
\hline \multicolumn{5}{|l|}{ Cultures } \\
\hline Color & Hair brown $\left(17^{\prime} \cdot{ }^{\prime} \mathrm{i}\right)$ & $\begin{array}{l}\text { Cream-buff }\left(19^{\prime} \mathrm{d}-\right) \text { to hair } \\
\text { brown }\left(17^{\prime \prime \prime} \mathrm{i}\right)\end{array}$ & $\begin{array}{l}\text { Cream-buff }\left(19^{\prime \prime} \mathrm{d}-\right) \text { to hair } \\
\text { brown }\left(17^{\prime} \cdot{ }^{\prime} \mathrm{i}\right)\end{array}$ & Wood brown (17') \\
\hline \multirow[t]{2}{*}{ Growth rate } & Opt. at $25-30^{\circ} \mathrm{C}$ & Opt. at $25-30^{\circ} \mathrm{C}$ & Opt. at $25-30^{\circ} \mathrm{C}$ & Opt at $30-35^{\circ} \mathrm{C}$ \\
\hline & $\begin{array}{l}\text { Good growth at } 35^{\circ} \mathrm{C} \text {, } \\
\text { no growth at } 4^{\circ} \mathrm{C}\end{array}$ & $\begin{array}{l}\text { Good growth at } 35^{\circ} \mathrm{C} \text {, } \\
\text { no growth at } 4^{\circ} \mathrm{C}\end{array}$ & $\begin{array}{l}\text { Good growth at } 35^{\circ} \mathrm{C} \text {, } \\
\text { no growth at } 4^{\circ} \mathrm{C}\end{array}$ & No growth at $4^{\circ} \mathrm{C}$ \\
\hline Hyphse & Smooth & Smooth & Smooth & Smooth \\
\hline \multicolumn{5}{|l|}{ Ascomatal bese } \\
\hline $\begin{array}{l}\text { Color } \\
\text { Length } \\
\text { Width }\end{array}$ & $\begin{array}{l}\text { Dark brown to black } \\
(116-) 149-205(-236) \mu \mathrm{m} \\
(130-) 161-217(-270) \mu \mathrm{m}\end{array}$ & $\begin{array}{l}\text { Dark brown to black } \\
(148-) 168-218(-293) \mu \mathrm{m} \\
(158-) 187-235(-296) \mu \mathrm{m}\end{array}$ & $\begin{array}{l}\text { Light brown or brown } \\
(65-) 82-122(-162) \mu \mathrm{m} \\
(82-) 100-146(-185) \mu \mathrm{m}\end{array}$ & $\begin{array}{l}\text { Dark brown to black } \\
(154-) 206-254(-279) \mu \mathrm{m} \\
\text { NA }\end{array}$ \\
\hline Shape & Globose to subglobose & Globose to subglobose & Globose to subglobose & Globose \\
\hline Omamentation & Spines with hyphal hairs & Spines with hyphal hairs & Spines with hyphal hairs & Spines with hyphal hairs \\
\hline \multicolumn{5}{|l|}{ Spines } \\
\hline $\begin{array}{l}\text { Color } \\
\text { Length }\end{array}$ & $\begin{array}{l}\text { Dark brown to black } \\
(18-) 20-30(-37) \mathrm{\mu m}\end{array}$ & $\begin{array}{l}\text { Dark brown to black } \\
(5-) 6-12(-18) \mu \mathrm{m}\end{array}$ & $\begin{array}{l}\text { Dark brown to black } \\
(4-) 6-12(-19) \mu \mathrm{m}\end{array}$ & $\begin{array}{l}\text { Dark brown to black } \\
(4-9-19(-26) \mu \mathrm{m}\end{array}$ \\
\hline \multicolumn{5}{|l|}{ Ascomatal necks } \\
\hline Color & Dark brown to black & Dark brown to black & Light brown to brown & Dark brown to black \\
\hline Disc form at base & Present & Present & Present & Present \\
\hline Length & $(347-) 393-575(-687) \mu \mathrm{m}$ & $(323-) 390-574(-687) \mu \mathrm{m}$ & $(185-) 301-499(-524) \mu \mathrm{m}$ & $(385-) 443-819(-1097) \mu \mathrm{m}$ \\
\hline Width (base) & $(66-) 83-119(-141) \mu \mathrm{m}$ & $(67-) 81-103(-128) \mu \mathrm{m}$ & $(41-) 57-81(-95) \mu \mathrm{m}$ & $(30-) 43-57(-64) \mu \mathrm{m}$ \\
\hline Width (tip) & $(14-) 16-20(-23) \mu \mathrm{m}$ & $(12-) 15-23(-32) \mu \mathrm{m}$ & $(8-) 10-14(-16) \mu \mathrm{m}$ & $(14-) 16-22(-26) \mu \mathrm{m}$ \\
\hline \multicolumn{5}{|l|}{ Ostiolar hyphae } \\
\hline Orientation & Divergent & Divergent & Divergen & Divergent \\
\hline Length & $(20-) 24-34(-38) \mu \mathrm{m}$ & $(21-) 24-32(-35) \mathrm{\mu m}$ & $(9-) 14-22(-25) \mu \mathrm{m}$ & $(10-) 18-36(-50) \mu \mathrm{m}$ \\
\hline Asci & Not seen & Not seen & Not seen & Not seen \\
\hline \multicolumn{5}{|l|}{ Ascospores } \\
\hline Color & Hyaline & Hyaline & Hyaline & Hyaline \\
\hline Shape (side view) & Cucullate & Cucullate & Cucullate & Hat-shaped \\
\hline \multicolumn{5}{|l|}{ Measurements } \\
\hline With shesth & $5-7 \times 2-4 \mu \mathrm{m}$ & $5-7 \times 3-4 \mu \mathrm{m}$ & $5-7 \times 2-4 \mu \mathrm{m}$ & $5-7 \times 2-4 \mu \mathrm{m}$ \\
\hline Without sheath & $4-6 \times 2-4 \mu \mathrm{m}$ & $4-6 \times 3-4 \mu \mathrm{m}$ & $4-6 \times 2-4 \mu \mathrm{m}$ & $4-6 \times 2-4 \mu \mathrm{m}$ \\
\hline \multicolumn{5}{|l|}{ Primary conidiophores } \\
\hline Length & $(18-) 22-32(-44) \mu \mathrm{m}$ & $(17-) 21-31(-38) \mu \mathrm{m}$ & $(18-) 22-36(-41) \mu \mathrm{m}$ & $(19-) 22-3 G(-56) \mu \mathrm{m}$ \\
\hline Width (base) & $3-5 \mu \mathrm{m}$ & $2-4(-5) \mu \mathrm{m}$ & $2-4(-5) \mu \mathrm{m}$ & $(1-) 2-4(-5) \mu \mathrm{m}$ \\
\hline Width (middle) & $2-4 \mu \mathrm{m}$ & $(2-) 2-4(-5) \mu \mathrm{m}$ & $2-4 \mu \mathrm{m}$ & NA \\
\hline Width (tip) & $1-3 \mu \mathrm{m}$ & $1-3 \mu \mathrm{m}$ & $1-2 \mu \mathrm{m}$ & $1-3 \mu \mathrm{m}$ \\
\hline Shape & Phialides & Phialides & Phialides & Phialides \\
\hline \multicolumn{5}{|c|}{ Secondary conidiophores } \\
\hline Length & $(19-) 23-35(-43) \mu \mathrm{m}$ & $(23-) 23-37(-47) \mu \mathrm{m}$ & None & NA \\
\hline Width (base) & $2-4(-5) \mu \mathrm{m}$ & $2-4 \mu \mathrm{m}$ & None & NA \\
\hline Width (tip) & $2-4(-5) \mu \mathrm{m}$ & $3-5 \mu \mathrm{m}$ & None & NA \\
\hline Shape & Phialides & Phialides & None & NA \\
\hline \multicolumn{5}{|l|}{ Primary conidia } \\
\hline Shape & Cylindrical & Cylindrical & Cylindrical & Cylindrical \\
\hline Length & $(5-) 6-8(-11) \mu \mathrm{m}$ & $5-(-8) \mu \mathrm{m}$ & $(3-) 4-6(-11) \mu \mathrm{m}$ & $6-8(-9) \mu \mathrm{m}$ \\
\hline Width & $(2-) 3-5(-7) \mu \mathrm{m}$ & $2-4(-5) \mu \mathrm{m}$ & $1-3 \mu \mathrm{m}$ & 2-3 $\mathrm{mm}$ \\
\hline \multicolumn{5}{|l|}{ Secondary conidia } \\
\hline Shape & Barrel-shaped & Barrel-shaped & None & Barrel-shaped \\
\hline Length & $(4-) 5-7(-8) \mu \mathrm{m}$ & $(4-) 5-7(-8) \mu \mathrm{m}$ & None & $(5-) 6-8(-10) \mu \mathrm{m}$ \\
\hline Width & $1-3 \mu \mathrm{m}$ & $1-3 \mu \mathrm{m}$ & None & $3-5 \mu \mathrm{m}$ \\
\hline Chlamydospores & Absent & Absent & Absent & Absent \\
\hline
\end{tabular}

Opt. optimal 


\section{Pathogenicity tests}

\section{Greenhouse inoculations}

All isolates inoculated in this study produced lesions on A. crassicarpa and A. mangium seedlings within 10 days of inoculation. The lesion lengths ranged from 21 to $67 \mathrm{~mm}$ on $A$. crassicarpa and 27-66 mm on A. mangium. Isolate CMW 21106 (group 1) consistently produced significantly longer lesions when compared with the controls on $A$. crassicarpa and A. mangium. Isolates residing in group 2 and group 3 also produced longer lesions than the controls; however, only one isolate of each group, namely, CMW 21113 (group 2) and CMW 21115 (group 3), produced lesions that were significantly different from the controls $\left[\mathrm{P}=0.05 ; \mathrm{r}^{2}=0.31\right.$; coefficient of variation $(\mathrm{CV})$ $=94.1$; root mean square error $(\mathrm{MSE})=35.5]$. Reisolations from the lesions consistently yielded $C$. moniliformis s.l. isolates, and these were never found associated with the control inoculations.

\section{Field inoculations}

All Ceratocystis isolates produced lesions on A. mangium and A. crassicarpa trees within 6 weeks of inoculation (Fig. 2). Lesion lengths ranged from 90 to $170 \mathrm{~mm}$ on A. crassicarpa and 140-250 $\mathrm{mm}$ on A. mangium trees (Fig. 3). Lesion lengths were significantly smaller on A. crassicarpa trees when compared to those on $A$. mangium. All isolates, other than CMW 21113, when inoculated on A. crassicarpa resulted in lesions that differed significantly from the controls $\left(\mathrm{P}=0.05 ; \mathrm{r}^{2}=0.37\right.$; $\mathrm{CV}=42.5$; root $\mathrm{MSE}=6.41$ ). Reisolations from the lesions failed to yield isolates of the inoculated fungi. Trees diameters ranged from 70 to $90 \mathrm{~mm}$ and had no impact on lesion length $\left(\mathrm{P}=0.05 ; \mathrm{r}^{2}=\right.$ $0.40 ; \mathrm{CV}=14.34$; root $\mathrm{MSE}=1.24$ ). 

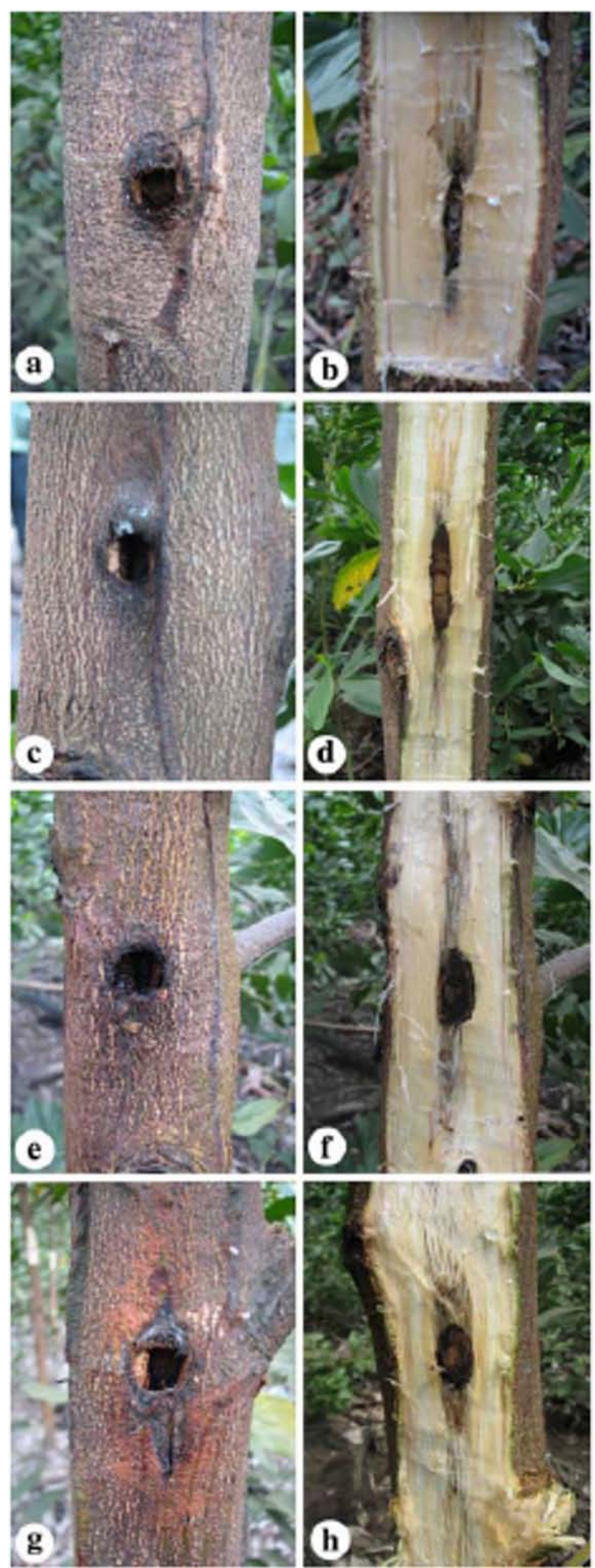
Fig. 2. Lesions on the bark and the cambium of 1-year-old Acacia mangium trees in Indonesia, 6 weeks after inoculation with Ceratocystis inquinans (CMW 21106), C. sumatrana (CMW 21113), and C. microbasis (CMW 21117). a. External/bark lesion for control inoculation. b. Internal/xylem lesion for control inoculation. c. External/bark lesion caused by $C$. inquinans. d. Internal/xylem lesion caused by $C$. inquinans. e. External/bark lesion caused by $C$. sumatrana. f. Internal/xylem lesion caused by $C$. sumatrana. g. External/bark lesion caused by C. microbasis. h. Internal/xylem lesion caused by $C$. microbasis.

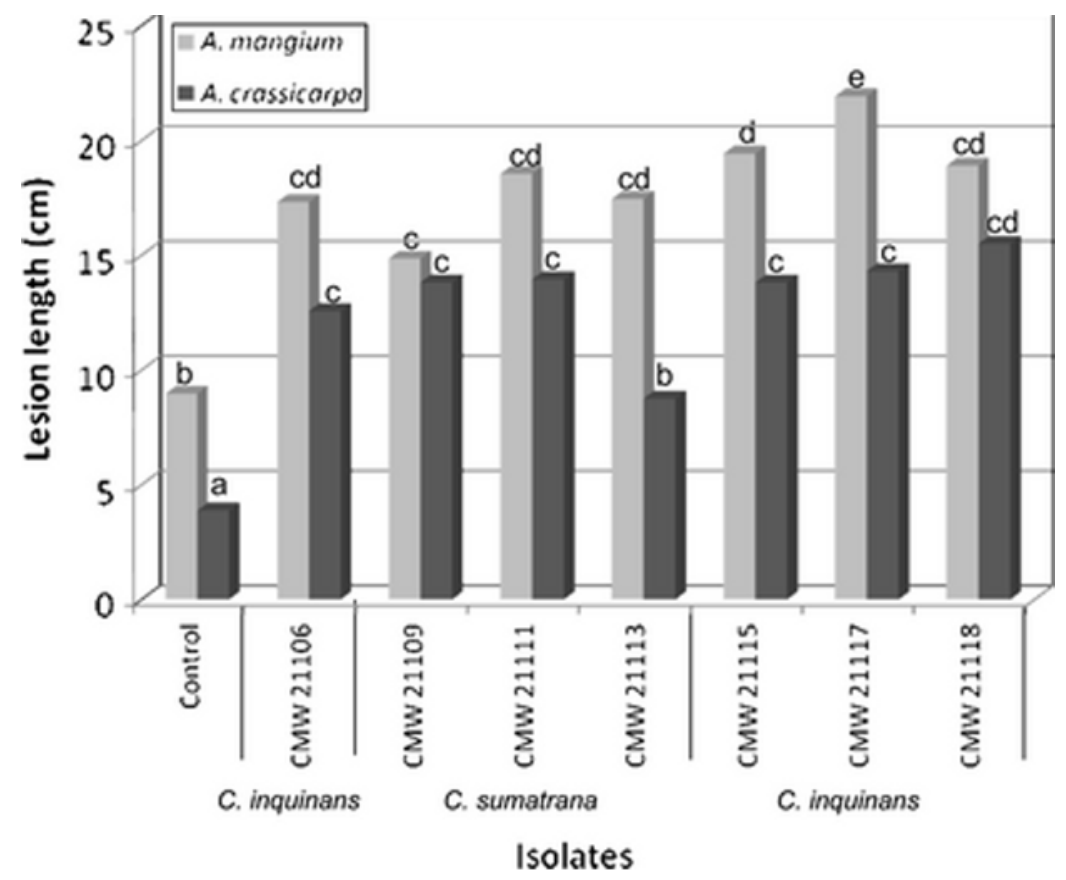

Fig. 3. Results of inoculations using Ceratocystis inquinans (CMW 21106), C. sumatrana (CMW 21109, CMW 21111, CMW 21113), and C. microbasis (CMW 21115, CMW 21117, CMW 21118) on 1-year-old Acacia mangium and A. crassicarpa trees in an Indonesian plantation, 6 weeks after inoculation. Bars on the graph indicated with the same letter are not significantly different from each other $(\mathrm{P}=0.05)$.

\section{Taxonomy}

Results of this study have shown that the three Ceratocystis spp. belonging to the $C$. moniliformis s.l. species complex isolated from wounded A. mangium in Indonesia represent previously undescribed taxa. They are consequently described as follows.

Ceratocystis inquinans Tarigan, M. van Wyk \& M.J. Wingf., sp. nov. Fig. 4. 


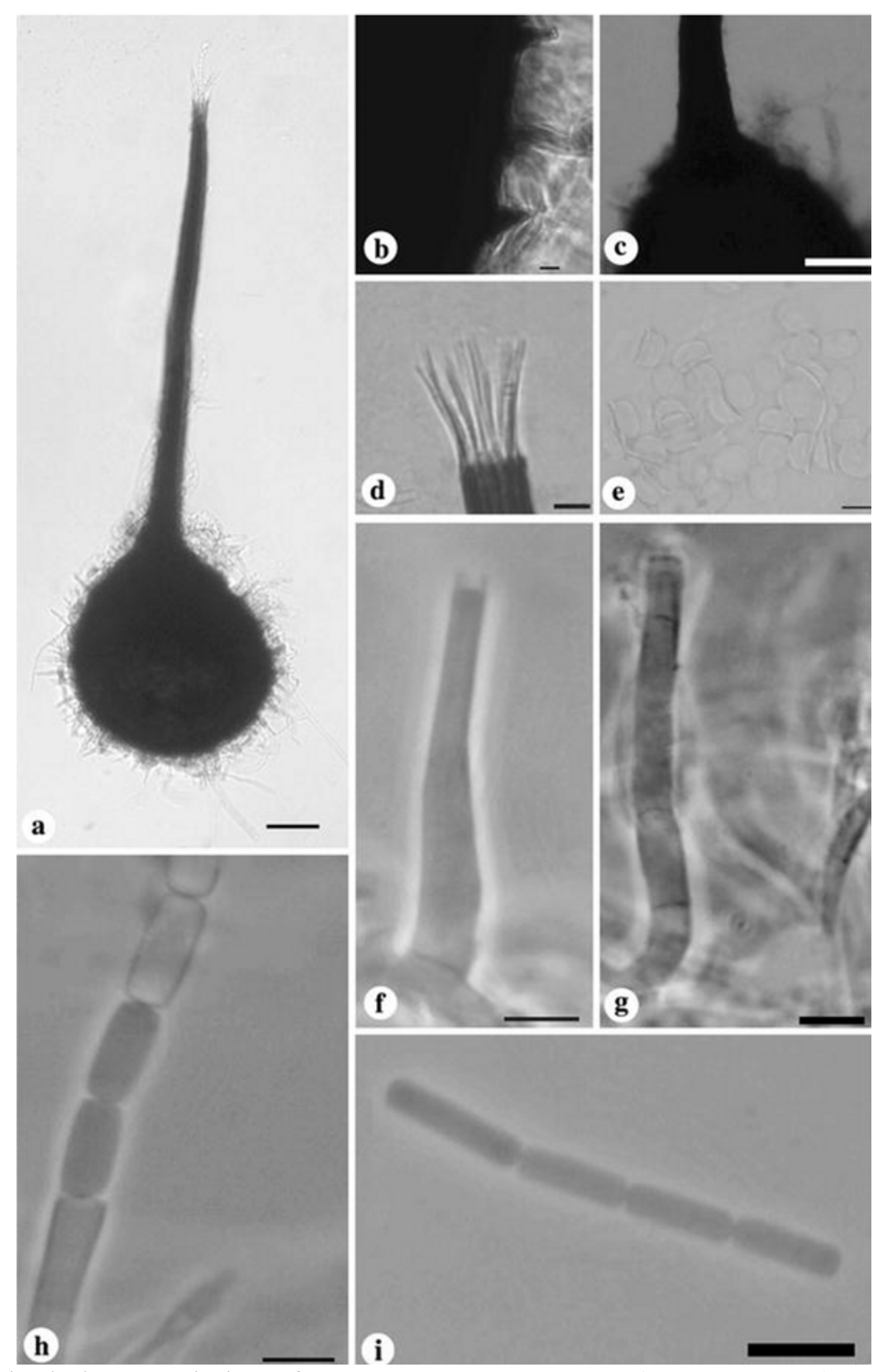

Fig. 4. Morphological characteristics of Ceratocystis inquinans (CMW 21106). a. Globose ascoma with long neck. b. Ascomatal base with conical spines and hyphal ornamentation. c. Ascomatal neck with disc-shaped attachment at base. d. Divergent ostiolar hyphae. e. Hat-shaped ascospores in side view. f. Primary phialide. g. Secondary phialide. h. Barrel-shaped conidia. i. Cylindrical conidia. Bars a, c, e $50 \mu \mathrm{m}$; d $10 \mu \mathrm{m} ; \mathrm{b}, \mathrm{f}-\mathrm{i} 5 \mu \mathrm{m}$.

MycoBank no.: MB 508828

Etymology: The name refers to the ability of this fungus to cause stain. Name derived from the Latin inquinans meaning "staining."

Anamorph: Thielaviopsis sp.

Coloniae crinobrunneae. Mycelium aerium. Hyphae laeves, septis non constrictis. Bases ascomatum atrobrunneae vel nigrae, globosae vel subglobosae (116-)149-205(-236) $\mu \mathrm{m}$ longae, (130-)161$217(-270) \mu \mathrm{m}$ latae, spinis hyphisque ornatae; spinae atrobrunneae vel nigrae (18-)20-30(-37) $\mu \mathrm{m}$ longae. Colla ascomatum atrobrunnea vel nigra, apicem versus pallentia (347-)393-575(-687) $\mu \mathrm{m}$ longa, basi (66-)83-119(-141) $\mu \mathrm{m}$, apice (14-)16-20(-23) $\mu \mathrm{m}$ lata, basi discoidea. Hyphae 
ostiolares divergentes, hyalinae, (20-)24-34(-38) $\mu \mathrm{m}$ longae. Asci non visi. Ascosporae in massis fulvo-flavescentibus mucosis in apicibus collorum ascomatum. Ascosporae lateraliter visae cucullatae hyalinae, non septatae, vaginis inclusae, 5-7 × 2-4 $\mu \mathrm{m}$ cum vagina, $4-6 \times 2-4 \mu \mathrm{m}$ sine illa.

Anamorpha Thielaviopsis: Conidiophorae primariae in mycelio singulae, hyalinae, basi incrassatae, apicem versus angustatae, $(18-) 22-32(-44) \mu \mathrm{m}$ longae, basi $3-5 \mu \mathrm{m}$, medio $2-4 \mu \mathrm{m}$, apice $1-3 \mu \mathrm{m}$ latae. Conidiophorae secondariae in mycelio singulae hyalinae (19-)23-35(-43) $\mu \mathrm{m}$ longae, basi apiceque (2-)2-4(-5) $\mu \mathrm{m}$ latae. Conidia biformia: primaria hyalina, cylindrica, non septata, (5-)6$8(-11) \times(2-) 3-5(-7) \mu \mathrm{m}$; secondaria hyalina, doliiformia, $(4-) 5-7(-8) \times 1-3 \mu \mathrm{m}$.

Colonies hair brown (17'"'i) in color. Mycelium aerial. Optimal temperature for growth $25-30^{\circ} \mathrm{C}$, no growth at $4{ }^{\circ} \mathrm{C}$, but growth observed at $35^{\circ} \mathrm{C}$. Hyphae smooth, not constricted at septa. Ascomatal bases dark brown to black, globose to subglobose, (116-)149-205(-236) $\mu \mathrm{m}$ high, (130-)161$217(-270) \mu \mathrm{m}$ wide, ornamented with spines and hyphae, spines dark brown to black, (18-)20-30(37) $\mu \mathrm{m}$ long. Ascomatal necks dark brown to black becoming lighter toward the apices, (347-)393575(-687) $\mu \mathrm{m}$ long, (66-)83-119(-141) $\mu \mathrm{m}$ wide at the base, $(14-) 16-20(-23) \mu \mathrm{m}$ wide at the apex, with a disc-like base. Ostiolar hyphae divergent, hyaline, (20-)24-34(-38) $\mu \mathrm{m}$ long. Asci not observed. Ascospores accumulating in buff-yellow (19d) mucilaginous masses at the apices of the ascomatal necks. Ascospores cucullate (hat-shaped) in side view, aseptate, hyaline, invested in sheath, 5-7 $\times 2-4 \mu \mathrm{m}$ with sheath, $4-6 \times 2-4 \mu \mathrm{m}$ without sheath.

Thielaviopsis anamorph: Primary conidiophores occurring singly on mycelium, hyaline, swollen at the bases, tapering toward the apices, (18-)22-32(-44) $\mu \mathrm{m}$ long, 3-5 $\mu \mathrm{m}$ wide at the bases, $2-4 \mu \mathrm{m}$ wide at the middle, $1-3 \mu \mathrm{m}$ wide at the apices. Secondary conidiophores occurring singly on mycelium, hyaline, (19-)23-35(-43) $\mu \mathrm{m}$ long, 2-4(-5) $\mu \mathrm{m}$ wide at the bases, 2-4(-5) $\mu \mathrm{m}$ wide at the apices. Conidia of two types: primary conidia hyaline, aseptate, cylindrical $(5-) 6-8(-11) \times$ $(2-) 3-5(-7) \mu \mathrm{m}$; and secondary conidia hyaline, aseptate, barrel-shaped (4-)5-7(-8) $\times 1-3 \mu \mathrm{m}$. Chlamydospores absent.

Habitat: Acacia mangium.

Known distribution: Sumatra, Indonesia.

Holotype: Indonesia. Sumatra. Isolated from Acacia mangium, 2005, M. Tarigan, (PREM 59866); living culture: CMW 21106 (CBS 124388).

Additional specimen examined: Indonesia, Sumatra. Isolated from Acacia mangium, 2005, M. Tarigan, (PREM 59867); living culture: CMW 21107 (CBS 124009).

Ceratocystis sumatrana Tarigan, M. van Wyk \& M.J. Wingf., sp. nov. Fig. 5. 


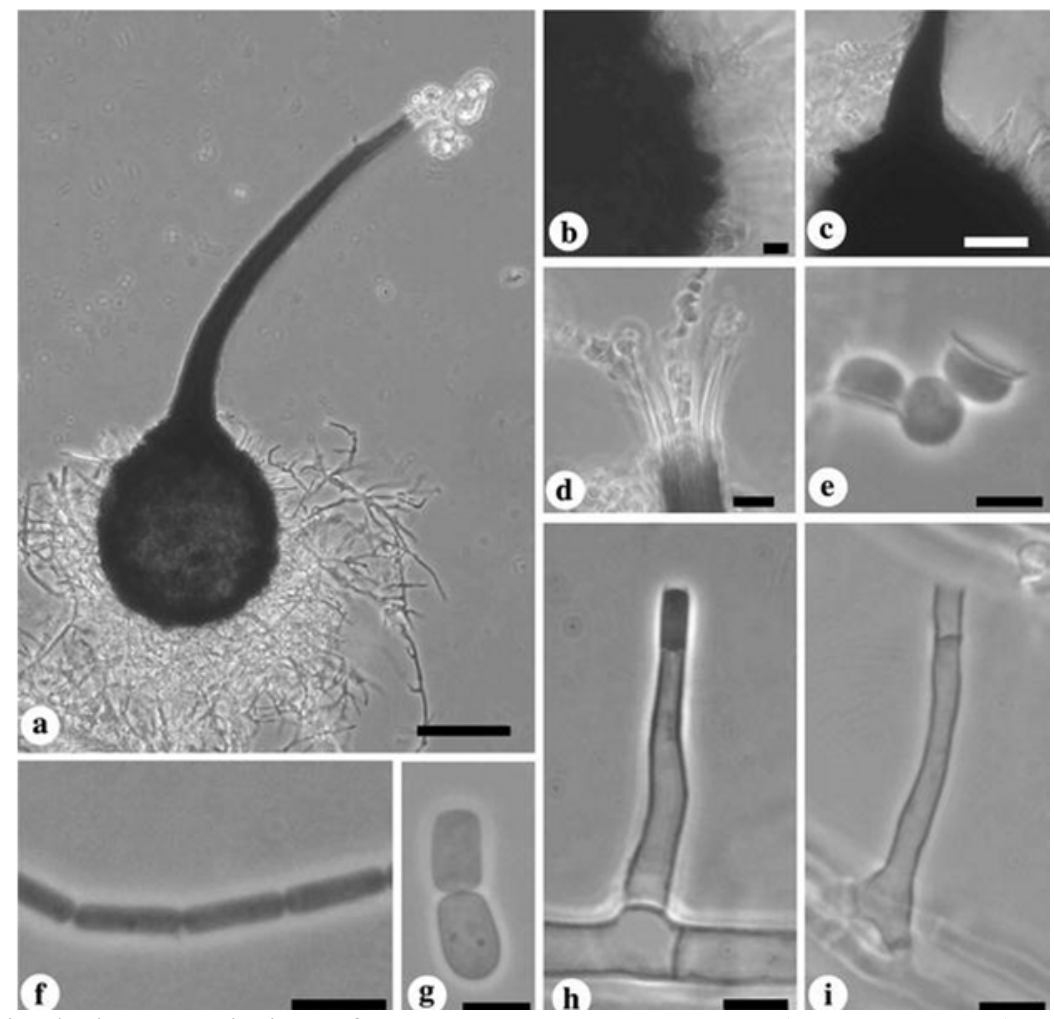

Fig. 5. Morphological characteristics of Ceratocystis sumatrana (CMW 21113). a. Globose ascoma with long neck. b. Ascomatal base with conical spines and hyphal ornamentation. c. Ascomatal neck with disc-shaped attachment at base. d. Divergent ostiolar hyphae. e. Hat-shaped ascospores in side view. f. Cylindrical conidia. g. Barrel-shaped conidia. h. Primary phialide. i. Secondary phialide. Bars a $100 \mu \mathrm{m}$; c, d $10 \mu \mathrm{m}$; b, e-i $5 \mu \mathrm{m}$.

\section{MycoBank no.: MB 508829}

Etymology: Name refers to the Indonesian island of Sumatra where this species was discovered.

\section{Anamorph: Thielaviopsis sp.}

Coloniae cremeo-fulvae vel crinobrunneae. Mycelium aerium. Hyphae laeves, septis non constrictis. Bases ascomatum atrobrunneae vel nigrae, globosae vel subglobosae (148-)168-218(293) $\mu \mathrm{m}$ longae, (158-)187-235(-296) $\mu \mathrm{m}$ latae, spinis hyphisque ornatae; spinae atrobrunneae vel nigrae (5-)6-12(-18) $\mu \mathrm{m}$ longae. Colla ascomatum atrobrunnea vel nigra, apicem versus pallentia (323-)390-574(-687) $\mu \mathrm{m}$ longa, basi (67-)81-103(-128) $\mu \mathrm{m}$, apice (12-)15-23(-32) $\mu \mathrm{m}$ lata, basi discoidea. Hyphae ostiolares divergentes hyalinae, (21-)24-32(-35) $\mu \mathrm{m}$ longae. Asci non visi. Ascosporae in massis fulvo-flavescentibus mucosis in apicibus collorum ascomatum. Ascosporae lateraliter visae cucullatae hyalinae, non septatae, vaginis inclusae, 5-7 × 3-4 $\mu \mathrm{m}$ cum vagina, 4-6 $\times 3-4 \mu \mathrm{m}$ sine illa.

Anamorpha Thielaviopsis: Conidiophorae primariae in mycelio singulae, hyalinae, basi incrassatae, apicem versus angustatae, (17-)21-31(-38) $\mu \mathrm{m}$ longae, basi 2-4(-5) $\mu \mathrm{m}$, medio $2-4(-5) \mu \mathrm{m}$, apice 1-3 $\mu \mathrm{m}$ latae. Conidiophorae secondariae in mycelio singulae, hyalinae, $23-37(-47) \mu \mathrm{m}$ longae, basi $2-4 \mu \mathrm{m}$, apice 3-5 $\mu \mathrm{m}$ latae. Conidia biformia: primaria hyalinae, cylindrica, non septata, 5$7(-8) \times 2-4(-5) \mu \mathrm{m}$; secondaria hyalina doliiformia, non septata, $(4-) 5-7(-8) \times 1-3 \mu \mathrm{m}$.

Colonies cream-buff (19"d) to hair brown (17"'"i) in color. Mycelium aerial. Optimal temperature for growth $25-30^{\circ} \mathrm{C}$, no growth at $4^{\circ} \mathrm{C}$, but growth observed at $35^{\circ} \mathrm{C}$. Hyphae smooth, not constricted at septa. Ascomatal bases dark brown to black, globose to subglobose, (148-)168-218(- 
293) $\mu \mathrm{m}$ high, (158-)187-235(-296) $\mu \mathrm{m}$ wide, ornamented with spines and hyphae, spines dark brown to black, (5-)6-12(-18) $\mu \mathrm{m}$ long. Ascomatal necks dark brown to black and becoming lighter toward the apices, (323-)390-574(-687) $\mu \mathrm{m}$ long, (67-)81-103(-128) $\mu \mathrm{m}$ wide at the bases, (12-) 15-23(-32) $\mu \mathrm{m}$ wide at the apices, with a disc-like base. Ostiolar hyphae divergent, hyaline, (21-)24-32(-35) $\mu \mathrm{m}$ long. Asci not observed. Ascospores accumulating in buff-yellow (19d) mucilaginous masses at the apices of the ascomatal necks. Ascospores cucullate (hat-shaped) in side view, aseptate, hyaline, invested in sheath, 5-7 $\times 3-4 \mu \mathrm{m}$ with sheath, 4-6 $\times 3-4 \mu \mathrm{m}$ without sheath.

Thielaviopsis anamorph: primary conidiophores occurring singly on mycelium, hyaline, swollen at the bases, tapering toward the apices, (17-)21-31(-38) $\mu \mathrm{m}$ long, 2-4(-5) $\mu \mathrm{m}$ wide at the bases, $2-$ $4(-5) \mu \mathrm{m}$ wide at the middle, $1-3 \mu \mathrm{m}$ wide at the apices. Secondary conidiophores occurring singly on mycelium, hyaline, 23-37(-47) $\mu \mathrm{m}$ long, 2-4 $\mu \mathrm{m}$ wide at the bases, $3-5 \mu \mathrm{m}$ wide at the apices. Conidia of two types: primary conidia hyaline, aseptate, cylindrical 5-7(-8) $\times 2-4(-5) \mu \mathrm{m}$, secondary conidia hyaline, aseptate, barrel-shaped (4-)5-7(-8) $\times 1-3 \mu \mathrm{m}$. Chlamydospores absent.

Habitat: Acacia mangium.

Known distribution: Sumatra, Indonesia.

Holotype: Indonesia. Sumatra. Acacia mangium, 2005, M. Tarigan, (PREM 59870); living culture: CMW 21113 (CBS 124010).

Additional specimens examined: Indonesia, Sumatra. Acacia mangium, 2005, M. Tarigan, (PREM 59868); living culture: CMW 21109 (CBS 124011). Indonesia, Sumatra. Acacia mangium, 2005, M. Tarigan, (PREM 59869); living culture: CMW 21111 (CBS 124012).

Ceratocystis microbasis Tarigan, M. van Wyk \& M.J. Wingf., sp. nov. Fig. 6. 


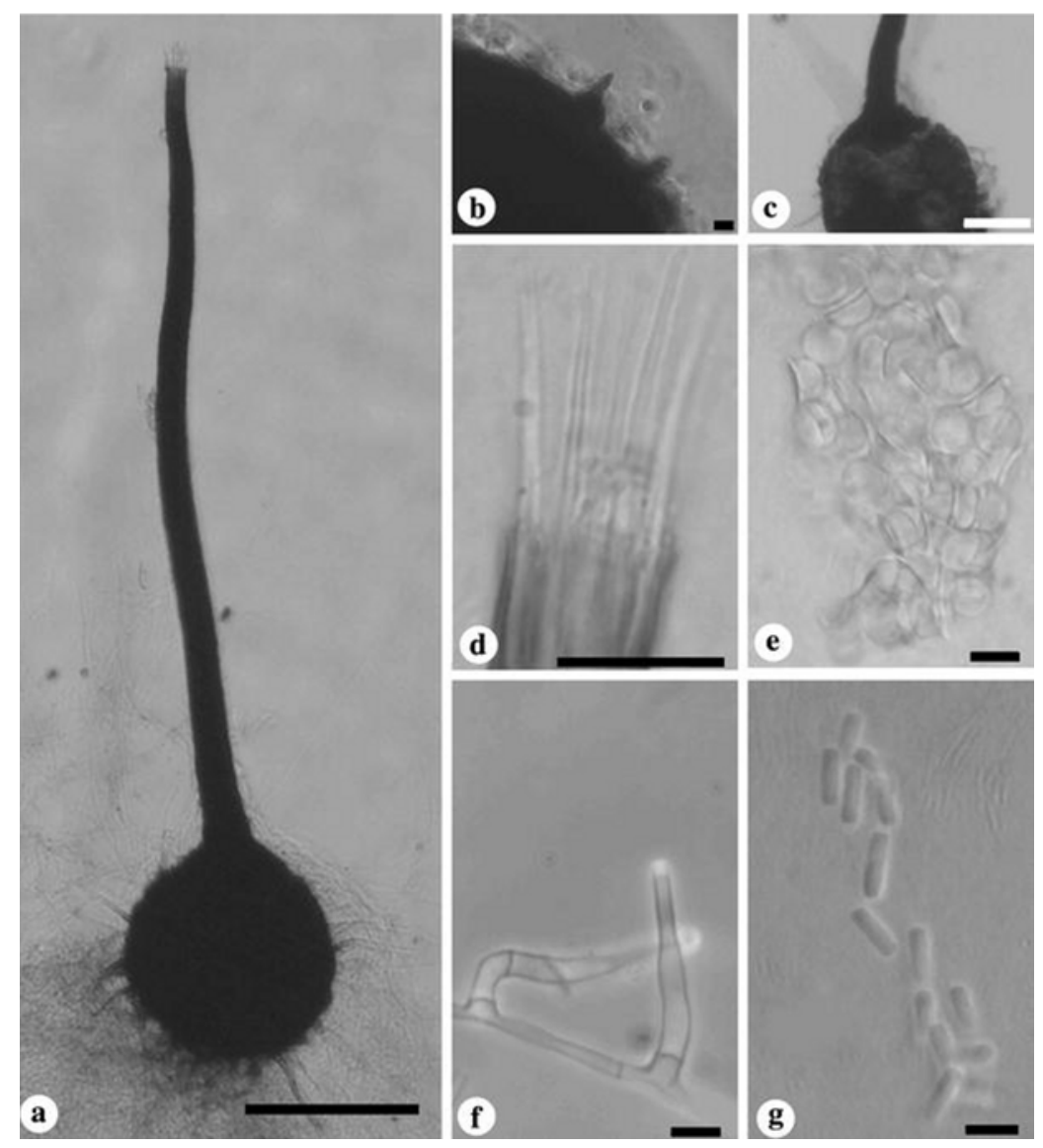

Fig. 6. Morphological characteristics of Ceratocystis microbasis (CMW 21117). a. Globose ascoma with long neck. b. Ascomatal base with conical spines and hyphal ornamentation. c. Ascomatal neck with disc-shaped attachment at base. $d$ Divergent ostiolar hyphae e. Hat-shaped ascospores in side view. f. Conidiophore/phialide. g. Cylindrical conidia. Bars a $100 \mu \mathrm{m}$; c $50 \mu \mathrm{m}$; d $10 \mu \mathrm{m}$; b, e-g 5 $\mu \mathrm{m}$.

MycoBank no.: MB 508945

Etymology: the name refers to the small ascomatal bases of this fungus.

Anamorph: Thielaviopsis sp.

Coloniae cremeo-fulvae vel crinobrunneae. Mycelium aerium. Hyphae laeves, septis non constrictis. Bases ascomatum pallide brunneae, atrobrunneae vel nigrae, globosae vel subglobosae (65-)82-122(-162) $\mu \mathrm{m}$ longae, (82-)100-146(-185) $\mu \mathrm{m}$ latae, spinis hyphisque ornatae; spinae atrobrunneae vel nigrae (4-)6-12(-19) $\mu \mathrm{m}$ longae. Colla ascomatum atrobrunnea vel nigra, apicem versus pallentia (185-)301-499(-574) $\mu \mathrm{m}$ longa, basi (41-)57-81(-95) $\mu \mathrm{m}$, apice (8-)10-14(-16) $\mu \mathrm{m}$ lata, basi discoidea. Hyphae ostiolares divergentes hyalinae, (9-)14-22(-25) $\mu \mathrm{m}$ longae. Asci non visi. Ascosporae in massis fulvo-flavescentibus mucosis in apicibus collorum ascomatum. Ascosporae lateraliter visae cucullatae hyalinae, non septatae, vaginis inclusae, 5-7 $\times 2-4 \mu \mathrm{m}$ cum vagina, $4-6 \times 2-4 \mu \mathrm{m}$ sine illa.

Anamorpha Thielaviopsis: Conidiophorae in mycelio singulae, hyalinae, basi incrassatae, apicem versus angustatae, (18-)22-36(-41) $\mu \mathrm{m}$ longae, basi 2-4(-5) $\mu \mathrm{m}$, medio $2-4 \mu \mathrm{m}$, apice 1-2 $\mu \mathrm{m}$ latae. Conidia hyalina, cylindrica, non septata, $(3-) 4-6(-11) \times 1-3 \mu \mathrm{m}$.

Colonies cream-buff (19"d) to hair brown (17"'"i) in color. Mycelium aerial. Optimal temperature for growth $25-30^{\circ} \mathrm{C}$, no growth at $4^{\circ} \mathrm{C}$, but growth observed at $35^{\circ} \mathrm{C}$. Hyphae smooth, not constricted at septa. Ascomatal bases light brown or dark brown to black, globose to sub globose, 
(65-)82-122(-162) $\mu \mathrm{m}$ high, (82-)100-146(-185) $\mu \mathrm{m}$ wide, ornamented with spines and hyphae, spines dark brown to black, (4-)6-12(-19) $\mu \mathrm{m}$ long. Ascomatal necks dark brown to black and becoming lighter toward the apices, (185-)301-499(-574) $\mu \mathrm{m}$ long, (41-)57-81(-95) $\mu \mathrm{m}$ wide at the bases, (8-)10-14(-16) $\mu \mathrm{m}$ wide at the apices, with disc-like bases. Ostiolar hyphae divergent, hyaline, (9-)14-22(-25) $\mu \mathrm{m}$ long. Asci not observed. Ascospores accumulating in buff-yellow (19d) mucilaginous masses at the apices of the ascomatal necks. Ascospores cucullate (hat-shaped) in side view, aseptate, hyaline, invested in sheath, 5-7 $\times 2-4 \mu \mathrm{m}$ with sheath, 4-6 $\times 2-4 \mu \mathrm{m}$ without sheath.

Thielaviopsis anamorph: primary conidiophores occurring singly on mycelium, hyaline, swollen at the bases, tapering toward the apices, (18-)22-36(-41) $\mu \mathrm{m}$ long, 2-4(-5) $\mu \mathrm{m}$ wide at the bases, $2-4$ $\mu \mathrm{m}$ wide at the middle, 1-2 $\mu \mathrm{m}$ wide at the apices. Secondary conidiophores, absent. Primary conidia hyaline, aseptate, cylindrical (3-)4-6(-11) $\times 1-3 \mu \mathrm{m}$. Secondary conidia, absent. Chlamydospores absent.

Habitat: Acacia mangium.

Known distribution: Sumatra, Indonesia.

Holotype: Indonesia. Sumatra. Acacia mangium. 2005, M. Tarigan, (PREM 59872); living culture: CMW 21117 (CBS 124017).

Additional specimens examined: Indonesia. Sumatra. Acacia mangium. 2005, M. Tarigan, (PREM 59871); living culture: CMW 21115 (CBS 124015). Indonesia. Sumatra. Acacia mangium. 2005, M. Tarigan, (PREM 59873), living culture: CMW 21118.

\section{Discussion}

In this study, three previously undescribed Ceratocystis spp. belonging to the C. moniliformis s.l. species complex were found associated with artificially induced wounds on A. mangium in Indonesia. These three fungi were recognized as undescribed taxa based on DNA sequence comparisons. Their unique nature was also confirmed based on morphology. Furthermore, we were able to show that these fungi are able to infect wounded A. mangium and A. crassicarpa trees in Indonesia. However, the inability to reisolate them from inoculated trees and the relatively limited lesions produced in pathogenicity tests suggests that they are not important pathogens.

The Ceratocystis spp. recognized in this study are all morphologically similar to species in the $C$. moniliformis species complex. In this respect, they all have long necks from which hat-shaped ascospores exude. More importantly, they all have globose bases ornamented with spines and their necks attach to the ascomatal bases with a distinct plate-like structure that easily becomes detached from the bases (Davidson 1935). Until recently, all species of Ceratocystis with these characteristics were broadly grouped within $C$. moniliformis. However, with the advent of DNA sequence comparisons, $C$. moniliformis has come to be recognized as an aggregate of several cryptic species for which some have been provided with names (Yuan and Mohammed 2002; Van Wyk et al. 2006b; Heath et al. 2009).

The three new species of Ceratocystis from Indonesia are morphologically very similar to each other. They all produce both teleomorph and anamorph structures in culture rapidly, typically within 1 week. However, the ability to produce these structures diminishes over time; this appears to be a common feature of species in the C. moniliformis complex (Van Wyk et al. 2004).

The three species described in this study can be relatively easily distinguished from each other (Table 1). Ceratocystis inquinans has hair brown aerial mycelium, which differs from C. sumatrana 
and C. microbasis, both of which have cream-buff to hair brown aerial mycelium. Ceratocystis inquinans and $C$. sumatrana have ascomatal bases, ascomatal necks and spines that are dark brown to black, whereas the ascomata of $C$. microbasis are lighter in color. Ceratocyctis microbasis can, furthermore, be distinguished from the other two species by the much smaller size of its teleomorph structures. The anamorph structures of the three new species are practically indistinguishable; however both $C$. inquinans and $C$. sumatrana have secondary conidiophores whereas $C$. microbasis has no secondary conidiophores.

Phylogenetically, the species from Indonesia are most closely related to $C$. omanensis, $C$. savannae Kamgan \& Jol. Roux, and C. bhutanensis M. van Wyk, M.J. Wingf. \& Kirisits (Table 2). This relationship is also supported by the similarity of some morphological characteristics of these new species with C. omanensis (Al-Subhi et al. 2006), C. savannae (Kamgan et al. 2008), C. bhutanensis (Van Wyk et al. 2004), C. oblonga Heath \& Jol. Roux (Heath et al. 2009), and T. ceramica Heath \& Jol. Roux (Heath et al. 2009). However, clear differences exist between these species. Ceratocystis omanensis and $C$. savannae have much longer ascomatal necks compared to Indonesian species and C. bhutanensis (Van Wyk et al. 2004; Al-Subhi et al. 2006; Kamgan et al. 2008). Species from Indonesia have hair brown or cream-buff to hair brown colonies, whereas $C$. omanensis has wood brown colonies, $C$. savannae has smoke grey colonies, and C. bhutanensis has cream-buff to dark olive to black colonies (Van Wyk et al. 2004; Al-Subhi et al. 2006; Kamgan et al. 2008). The secondary conidia of $C$. oblonga have a very characteristic oblong shape with truncated ends that distinguishes it from all other species in the $C$. moniliformis complex, and it has oblong ascomatal bases (Heath et al. 2009). Ascomata of $T$. ceramica have not been seen (Heath et al. 2009) and distinguishing it from the newly described species must rely largely on phylogenetic inference, although the species described in this study produce ascomata readily, and this feature might also be considered diagnostic.

Table 2. Isolates of Ceratocystis $(C$.) included in the phylogenetic analyses. 


\begin{tabular}{|c|c|c|c|c|c|}
\hline Species & Isolate no. & $\begin{array}{l}\text { GenBank } \\
\text { accession no. }\end{array}$ & Host & Geographic origin & Collector \\
\hline C. bhasanensis & $\begin{array}{l}\text { CMW } 8217 \\
\text { CBS } 114289 \\
\text { PREM } 57807\end{array}$ & $\begin{array}{l}\text { AY528957 } \\
\text { AY528962 } \\
\text { AY528952 }\end{array}$ & Picea spindosa & Bhatan & T Kirisits and DB Chetri \\
\hline C. bhusinensis & $\begin{array}{l}\text { CMW } 8242 \\
\text { CBS } 112907 \\
\text { PREM } 57809\end{array}$ & $\begin{array}{l}\text { AY528956 } \\
\text { AY528961 } \\
\text { AY528951 }\end{array}$ & P. spinedosa & Bhutan & T Kirisits and DB Chhetri \\
\hline C. inquinans " & CMW 21106 & $\begin{array}{l}\text { EU588587 } \\
\text { EU } 588666 \\
\text { EU } 588674\end{array}$ & Acacia mangium & Indonesia & M Tarigan \\
\hline C. inquinans & $\begin{array}{l}\text { CMW } 21107 \\
\text { CBS } 124009\end{array}$ & $\begin{array}{l}\text { EU } 588588 \\
\text { EU } 588667 \\
\text { EU } 588675\end{array}$ & A. mangùum & Indonesia & M Tarigan \\
\hline C. microbasis & $\begin{array}{l}\text { CMW } 21115 \\
\text { CBS } 124015\end{array}$ & $\begin{array}{l}\text { EU } 588592 \\
\text { EU } 588671 \\
\text { EU } 588679\end{array}$ & A. mangüum & Indonesia & M Tarigan \\
\hline C. microbasis & $\begin{array}{l}\text { CMW } 21117 \\
\text { CBS } 124013\end{array}$ & $\begin{array}{l}\text { EU } 588593 \\
\text { EU } 588672 \\
\text { EU } 588680\end{array}$ & A. mangàum & Indenesia & M Tarigan \\
\hline C. microbasis & CMW 21118 & $\begin{array}{l}\text { EU } 588594 \\
\text { EU } 588673 \\
\text { EU } 588681\end{array}$ & A. mangum & Indonesia & M Tarigan \\
\hline C. monithfonnis & $\begin{array}{l}\text { CMW } 4114 \\
\text { CBS } 118181\end{array}$ & $\begin{array}{l}\text { AY528997 } \\
\text { AY528986 } \\
\text { AY529007 }\end{array}$ & Schizolobiem parahybum & Ecuador & MJ Wingfield \\
\hline C. moniatfonnis & $\begin{array}{l}\text { CMW } 9590 \\
\text { CBS } 116452\end{array}$ & $\begin{array}{l}\text { AY431101 } \\
\text { AY528985 } \\
\text { AY529006 }\end{array}$ & Eucalypeus grandis & South Africa & J Roux \\
\hline C. monibfomopsis & $\begin{array}{l}\text { CMW } 9986 \\
\text { CBS } 109441\end{array}$ & $\begin{array}{l}\text { AY528998 } \\
\text { AY528987 } \\
\text { AY529008 }\end{array}$ & E. obliqua & Australia & ZQ Yuan \\
\hline C. monithfonnopsis & $\begin{array}{l}\text { CMW } 10214 \\
\text { CBS } 115792\end{array}$ & $\begin{array}{l}\text { AY528999 } \\
\text { AY528988 } \\
\text { AY529009 }\end{array}$ & E. sieberi & Australia & MJ Dudzinski \\
\hline C obbonga & $\begin{array}{l}\text { CMW } 23802 \\
\text { CBS } 122820\end{array}$ & $\begin{array}{l}\text { EU245020 } \\
\text { EU244992 } \\
\text { EU244952 }\end{array}$ & Acacia memsii & Soush Africa & RN Heath \\
\hline C obbonga & $\begin{array}{l}\text { CMW } 23803 \\
\text { CBS } 122291\end{array}$ & $\begin{array}{l}\text { EU245019 } \\
\text { EU244991 } \\
\text { EU244951 }\end{array}$ & A. memsit & Sough Africa & RN Heath \\
\hline C. omanensis & $\begin{array}{l}\text { CMW } 11048 \\
\text { CBS } 115780 \\
\text { PREM } 57815\end{array}$ & $\begin{array}{l}\mathrm{DQ} 074742 \\
\mathrm{DQ} 024732 \\
\mathrm{DQ} 024737\end{array}$ & Mangifera indisa & Oman & AO Al Adawi \\
\hline C. omanensis & $\begin{array}{l}\text { CMW } 11046 \\
\text { CBS } 118112 \\
\text { PREM } 57814\end{array}$ & $\begin{array}{l}\text { DQ074739 } \\
\text { DQ074729 } \\
\text { DQ074734 }\end{array}$ & M. indica & Oman & AO Al Adawi \\
\hline C. savannae & $\begin{array}{l}\text { CMW } 17300 \\
\text { PREM } 59423\end{array}$ & $\begin{array}{l}\text { EF408551 } \\
\text { EF408565 } \\
\text { EF408572 }\end{array}$ & Acacia nigrescens & South Africa & GN Kamgan \& J Roux \\
\hline C. savannae & $\begin{array}{l}\text { CMW } 17298 \\
\text { CBS } 121022\end{array}$ & $\begin{array}{l}\text { EF408551 } \\
\text { EF408551 } \\
\text { EF408551 }\end{array}$ & Terminalia sericea & South Africa & GN Kamgan \& J Roux \\
\hline C. sumatrana & $\begin{array}{l}\text { CMW } 21109 \\
\text { CBS } 124011\end{array}$ & $\begin{array}{l}\text { EU588589 } \\
\text { EU588668 } \\
\text { EU588676 }\end{array}$ & A. mangiam & Indonesha & M Tarigan \\
\hline C. sumatrana & $\begin{array}{l}\text { CMW } 21111 \\
\text { CBS } 124012\end{array}$ & $\begin{array}{l}\text { EU588590 } \\
\text { EU588669 } \\
\text { EU588677 }\end{array}$ & A. mangium & Indonesia & M Tarigan \\
\hline C. sumatrana & $\begin{array}{l}\text { CMW } 21113 \\
\text { CBS } 124010\end{array}$ & $\begin{array}{l}\text { EU588591 } \\
\text { EU588670 } \\
\text { EU588678 }\end{array}$ & A. mangium & Indonesh & M Tarigan \\
\hline C. tribilyormis & $\begin{array}{l}\text { CMW } 13012 \\
\text { CBS } 118242 \\
\text { PREM } 57826\end{array}$ & $\begin{array}{l}\text { AY529002 } \\
\text { AY528992 } \\
\text { AY529013 }\end{array}$ & Pinus merikusï & Indonesia & MJ Wingfield \\
\hline C. tribilyormis & $\begin{array}{l}\text { CMW } 13013 \\
\text { PREM } 57827 \\
\text { CBS } 115866\end{array}$ & $\begin{array}{l}\text { AY } 529003 \\
\text { AY528993 } \\
\text { AY529014 }\end{array}$ & P. merikusï & Indonesia & MJ Wingfield \\
\hline Cvirescens & $\begin{array}{l}\text { OMW } 3276 \\
\text { CBS } 123216\end{array}$ & $\begin{array}{l}\text { DQ061281 } \\
\text { AY528990 } \\
\text { AY529011 }\end{array}$ & Quercus sp. & USA & T Hinds \\
\hline C. virescens & $\begin{array}{l}\text { CMW } 11164 \\
\text { CBS } 123166\end{array}$ & $\begin{array}{l}\text { DQ520639 } \\
\text { EF070441 } \\
\text { EF070413 }\end{array}$ & Fagas americanien & USA & D Houston \\
\hline T. cenamica & $\begin{array}{l}\text { CMW } 15245 \\
\text { CBS } 122299\end{array}$ & $\begin{array}{l}\text { EU245022 } \\
\text { EU244994 } \\
\text { EU244926 }\end{array}$ & E grandis & Mabwi & RN Heath \\
\hline T. cenamica & $\begin{array}{l}\text { CMW } 15248 \\
\text { CBS } 122300\end{array}$ & $\begin{array}{l}\text { EU245024 } \\
\text { EU244996 } \\
\text { EU244928 }\end{array}$ & E. grandis & Malawi & RN Heath \\
\hline
\end{tabular}

- Sequences in boldface are the new species described in this article, and were the only ones sequenced in this study; the rest of the sequences were obtained from previous studies 
The Ceratocystis spp. described in this study all have temperature optima at $30^{\circ} \mathrm{C}$, which is consistent with the area in which they are found, where temperatures range between $25^{\circ}$ and $30^{\circ} \mathrm{C}$ throughout the year. All isolates also grew well at $35^{\circ} \mathrm{C}$, but they showed substantially reduced growth at temperatures below $20^{\circ} \mathrm{C}$ and failed to grow at $4^{\circ} \mathrm{C}$. These growth trends are similar to those reported for C. omanensis and C. savannae (Al-Subhi et al. 2006; Kamgan et al. 2008), other species originating from areas with warm climates. In contrast, they differ markedly from $C$. bhutanensis (Van Wyk et al. 2004), C. tribiliformis (Van Wyk et al. 2006b), C. moniliformis (Hedgcock 1906), C. moniliformopsis (Yuan and Mohammed 2002), C. oblonga (Heath et al. 2009), and T. ceramica (Heath et al. 2009), which have lower temperature optima for growth and most of which originate from areas with cooler climates.

The three new Ceratocystis spp. from wounds on A. mangium were able to cause relatively short lesions on inoculated trees that were significantly different from the controls. In the field inoculations, the lesions produced on A. mangium trees were longer than those on A. crassicarpa, which is consistent with the fact that $A$. mangium is sensitive to wounding (Schmitt et al. 1995). However, infections appeared to be short lived in the stems of trees, and we were not able to reisolate them from lesions. This result, together with the fact that no signs of disease were observed in either the greenhouse and field inoculations or on the trees from which the fungi were isolated, suggests that they are not significant pathogens. This finding is also consistent with what has been observed for other members of the C. moniliformis species complex (Davidson 1935; Bakshi 1951; Hunt 1956; Al-Subhi et al. 2006).

This study resulted in the description of three previously unknown Ceratocystis spp. from a limited geographic area in Indonesia. These results, and the fact that three new species were isolated from three trees with one species per tree, clearly emphasize the general lack of information on fungal diversity in general, even in relatively well studied environments.

\section{Acknowledgments}

We thank the National Research Foundation (NRF), members of the Tree Protection Co-operative Programme (TPCP), the THRIP initiative of the Department of Trade and Industry and the Department of Science and Technology (DST)/NRF Centre of Excellence in Tree Health Biotechnology (CTHB) for funding. We also acknowledge Riau Anadalan Pulp and Paper for making trees available for this study. Dr. Hugh Glen provided the Latin descriptions and suggested names for the new species, for which we are most grateful.

\section{Literature Cited}

Al-Subhi AM, Al Adawi AO, Van Wyk M, Deadman ML, Wingfield MJ (2006) Ceratocystis omanensis, a new species from diseased mango trees in Oman. Mycol Res 110:237-245.

Bakshi BK (1951) Studies on four species of Ceratocystis, with a discussion of fungi causing sapstain in Britain. Mycol Pap 35:1-16.

Barker FK, Lutzoni FM (2002) The utility of the incongruence length difference test. Syst Biol 51:625-637.

Barnes I, Roux J, Wingfield BD, Dudzinski MJ, Old KM, Wingfield MJ (2003) Ceratocystis pirilliformis, a new species from Eucalyptus nitens in Australia. Mycologia 95:865-871.

Beadle C, Barry K, Hardiyanto E, Irianto R, Junarto Mohammed C, Rimbawanto A (2007) Effect of 
pruning Acacia mangium on growth, form and heart rot. Forest Ecol Manag 238:261-267.

Carbone I, Kohn LM (1999) A method for designing primer sets for speciation studies in filamentous ascomycetes. Mycologia 91:553-556.

Cunningham CW (1997) Can three incongruence tests predict when data should be combined? Mol Biol Evol 14:733-740.

Davidson RW (1935) Fungi causing stain in logs and lumber in the Southern states, including five new species. J Agric Res 50:789-807.

Glass NL, Donaldson GC (1995) Development of primer sets designed for use with PCR to amplify conserved genes from filamentous Ascomycetes. Appl Environ Microbiol 61:1323-1330.

Heath RN, Wingfield BD, Wingfield MJ, Meke G, Mbaga A, Roux J (2009) Ceratocystis species on Acacia mearnsii and Eucalyptus spp. in eastern and southern Africa including six new species. Fungal Divers 34:41-68.

Hedgcock GG (1906) Studies upon some chromogenic fungi which discolor wood. Miss Bot Gar 17:59-124.

Hunt J (1956) Taxonomy of the genus Ceratocystis. Lloydia 19:1-58.

Kamgan NG, Jacobs K, De Beer ZW, Wingfield MJ, Roux J (2008) Ceratocystis and Ophiostoma species, including three new taxa, associated with wounds on native South African trees. Fungal Divers 29:37-59.

Kile GA (1993) Plant diseases caused by species of Ceratocystis sensu stricto and Chalara. In: Wingfield MJ, Seifert KA, Webber JF (eds) Ceratocystis and Ophiostoma: taxonomy, ecology and pathogenicity. APS Press, St. Paul, pp 173-183.

Lee SS, Arentz F (1997) A possible link between rainfall and heart rot incidence in Acacia mangium? J Trop For Sci 9:441-448.

Morris MJ, Wingfield MJ, De Beer C (1993) Gummosis and wilt of Acacia mearnsii in South Africa caused by Ceratocystis fimbriata. Plant Pathol 42:814-817.

Nylander JAA (2004) MrModeltest v2. Program distributed by the author. Evolutionary Biology Centre, Uppsala University, Sweden.

Old KM, Lee SS, Sharma JK, Yuan ZQ (2000) A manual of diseases of tropical acacias in Australia, South-East Asia and India. Center for International Forestry Research, Bogor.

Old KM, Wingfield MJ, Yuan ZQ (2003) A manual of diseases of eucalypts in South-East Asia. Australian Centre for International Research, Canberra and Center for International Forestry Research. Bogor, Indonesia.

Rayner RW (1970) A mycological colour chart. Commonwealth Mycological Institute Kew, Surrey, and British Mycological Society.

Ribeiro IJA, Ito MF, Filho OP, De Castro JP (1988) Gomose da Acacia negra causada por Ceratocystis fimbriata Ell. \& Halst. Brag Camp 47:71-74. 
Ronquist F, Huelsenbeck JP (2003) MrBayes 3: Bayesian phylogenetic inference under mixed models. Bioinformatics 19:1572-1574.

Roux J, Wingfield MJ (1997) Survey and virulence of fungi occurring on diseased Acacia mearnsii in South Africa. For Ecol Manag 99:327-336.

Roux J, Meke G, Kanyi B, Mwangi L, Mbaga A, Hunter GC, Nakabonge G, Heath RN, Wingfield MJ (2005) Diseases of plantation forestry tree species in Eastern and Southern Africa. S Afr J Sci 101:409-413.

Roux J, Heath RN, Labuschagne L, Nkuekam GK, Wingfield MJ (2007) Occurrence of the wattle wilt pathogen, Ceratocystis albifundus on native South African trees. For Pathol 37:1-11.

SAS Institute (2001) SAS statistical software, SAS/STAT users guide, version 8.2. SAS Institute Inc, Cary, NC.

Schmitt U, Liese W, Hong LT, KillmannW (1995) The mechanism of wound response in Acacia mangium. IAWA J 16:425-432.

Srivastava PBL (1993) Silvicultural practice. In: Awang K, Taylor D (eds) Acacia mangium growing and utilization. MPTS monograph series. Winrock International and FAO, Bangkok, pp 113-147.

Swofford DL (2002) PAUP*: phylogenetic analysis using parsimony (* and other methods), ver 4. Sinauer Associates, Sunderland, MA.

Teviotdale BL, Harper DH (1991) Infection of pruning and small bark wounds in almond by Ceratocystis fimbriata. Plant Dis 75:1026-1030.

Van Wyk M, Roux J, Barnes I, Wingfield BD, Chhetri DB, Kirisits T, Wingfield MJ (2004) Ceratocystis bhutanensis sp. nov., associated with the bark beetle Ips schmutzenhoferi on Picea spinulosa in Bhutan. Stud Mycol 50:365-379.

Van Wyk M, Van der Merwe NA, Roux J, Wingfield BD, Kamgan GN, Wingfield MJ (2006a) Population genetic analyses suggest that the Eucalyptus fungal pathogen Ceratocystis fimbriata has been introduced into South Africa. S Afr J Sci 102:259-263.

Van Wyk M, Roux J, Barnes I, Wingfield BD, Wingfield MJ (2006b) Molecular phylogeny of the Ceratocystis moniliformis complex and description of $C$. tribiliformis sp. nov. Fungal Divers 21:181-201.

White TJ, Bruns T, Lee S, Taylor J (1990) Amplification and direct sequencing of fungal ribosomal RNA genes for phylogenetics. In: Innis MA, Gelfand DH, Sninsky JJ, White TJ (eds) PCR protocols: a sequencing guide to methods and applications. Academic Press, San Diego, pp 315322.

Wingfield MJ, De Beer C, Visser C, Wingfield BD (1996) A new Ceratocystis species defined using morphological and ribosomal DNA sequence comparisons. Syst Appl Microbiol 19:191-202.

Yuan ZQ, Mohammed C (2002) Ceratocystis moniliformopsis sp. nov., an early colonizer of Eucalyptus obliqua logs in Tasmania, Australia. Aust Syst Bot 15:125-133. 
Zalasky H (1965) Process of Ceratocystis fimbriata infection in Aspen. Can J Bot 43:1153-1162. 